\title{
"Corporate social responsibility policies and value creation: does corporate governance and profitability mediate that relationship?"
}

Josua Tarigan iD http://orcid.org/0000-0003-2729-7433

AUTHORS

Saarce Elsye Hatane id https://orcid.org/0000-0002-3797-1623

Linneke Stacia

Deborah Christine Widjaja iD https://orcid.org/0000-0001-5867-7530

Josua Tarigan, Saarce Elsye Hatane, Linneke Stacia and Deborah Christine Widjaja (2019). Corporate social responsibility policies and value creation: does ARTICLE INFO corporate governance and profitability mediate that relationship?. Investment Management and Financial Innovations, 16(2), 270-280. doi:10.21511/imfi.16(2).2019.23

DOI http://dx.doi.org/10.21511/imfi.16(2).2019.23

RELEASED ON Thursday, 20 June 2019

RECEIVED ON Monday, 11 February 2019

ACCEPTED ON Wednesday, 29 May 2019

\section{(cc) EY}

LICENSE

This work is licensed under a Creative Commons Attribution 4.0 International License

JOURNAL "Investment Management and Financial Innovations"

ISSN PRINT $1810-4967$

ISSN ONLINE $1812-9358$

PUBLISHER

LLC "Consulting Publishing Company "Business Perspectives"

FOUNDER

LLC "Consulting Publishing Company "Business Perspectives"

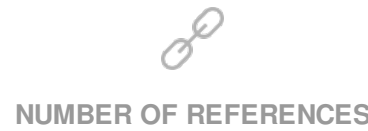

35
NUMBER OF FIGURES

1
NUMBER OF TABLES

9

(C) The author(s) 2022. This publication is an open access article. 


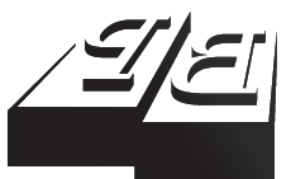

BUSINESS PERSPECTIVES

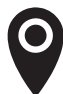

LLC "CPC "Business Perspectives" Hryhorii Skovoroda lane, 10, Sumy, 40022, Ukraine

www.businessperspectives.org

Received on: $11^{\text {th }}$ of February, 2019 Accepted on: $29^{\text {th }}$ of May, 2019

(C) Josua Tarigan, Saarce Elsye Hatane, Linneke Stacia, Deborah Christine Widjaja, 2019

Josua Tarigan, Dr., Department of Accounting, Petra Christian University, Indonesia.

Saarce Elsye Hatane, MBA, Department of Accounting, Petra Christian University, Indonesia.

Linneke Stacia, BBA, Department of Accounting, Petra Christian University, Indonesia.

Deborah Christine Widjaja, Dr., Petra Christian University, Indonesia.

\section{() (i)}

This is an Open Access article, distributed under the terms of the Creative Commons Attribution 4.0 International license, which permits unrestricted re-use, distribution, and reproduction in any medium, provided the original work is properly cited.
Josua Tarigan (Indonesia), Saarce Elsye Hatane (Indonesia),

Linneke Stacia (Indonesia), Deborah Christine Widjaja (Indonesia)

\section{CORPORATE SOCIAL RESPONSIBILITY POLICIES AND VALUE CREATION: DOES CORPORATE GOVERNANCE AND PROFITABILITY MEDIATE THAT RELATIONSHIP?}

\begin{abstract}
With a purpose to give a deep understanding relating to the manifestation of social responsibilities practices among Indonesian companies, this paper reflects the relationship of corporate social responsibility (CSR), corporate profitability (CP), value creation (VC) and good corporate governance (GCG). Kinder, Lydenberg, and Domini's (KLD) measurement approach is used in this study to measure the social responsibility practices, as this gives cross-border analysis of social responsibility. Corporate profitability captures return on assets, which is accounting-based measurement, whereas value creation explains the economic value added, which is shareholder-based measurement. Structural Equation Model (SEM) analysis is conducted for Indonesian listed companies, which appeared in Corporate Governance Perception Index (CGPI). The empirical result suggests that CSR serves as a tool in assisting shareholders value and performance. Accordingly, firms should incorporate CSR practices to enhance its strategic investment and sustain a strong relationship with its stakeholders. Subsequently, management should also take concern of having good corporate governance in order to improve company's perfor mance by supervising and monitoring of the company's operation, ensure the fulfillment to the stakeholder's interest. This paper presents fresh insights into applications of corporate social responsibility principles and corporate governance in Indonesian context that has not received systematic attention and consideration in the literature.
\end{abstract}

\section{Keywords}

Kinder, Lydenberg, and Domini's, economic value added, return on assets, Corporate Governance Perception Index

\section{JEL Classification $\quad$ M4, Q5, G3}

\section{INTRODUCTION}

In the traditional perspective, it is believed that business objective is to maximize the shareholder's wealth. However, as business grows, society comes up with different perspective on how organization should operate. In this case, companies should shift from the mindset of enriching only shareholders to focusing on all the stakeholders, including environmental sustainability and community welfare. It is also becoming more important for companies to fulfill the environmental expectation in order to gain its reputation, which further influences the firm's performance (Vargas, 2016).

Corporate social responsibility is considered to relate to corporate governance, as governance is positively associated with the environmental strength of a firm (Stuebs \& Sun, 2010). Not only that, previous study describes that good corporate governance could not be able to increase reputation and performance of the company without also doing social responsibility practices (Chalise, 2014). Recent studies have also analyzed the relationship of CSR and corporate governance from 
environmental performance perspective. The result shows a positive correlation on the study (Stuebs \& Sun, 2010). This is because corporate governance highlights the framework to form an environment, which is transparent, accountable and trusted. It also refers to how companies are being directed and controlled to avoid disputes between agents and investors and ensure that funds managed by agents are used accordingly (Detthamrong, Chancharat, \& Vithessonthi, 2017).

However, looking at the enforcement of CSR in Indonesia, this has been just a voluntary disclosure for many years. Meanwhile, starting from July 2007, Indonesian government has enforced a new regulation regarding CSR practices disclosure. Despite the large number of studies on CSR in the context of developed and moderately developed economies, whether or not CSR promote financial performance in the context of less developed and emerging economies has been relatively unexplored. Additionally, very few studies have examined the roles of corporate governance (CG) as intervening variable. Therefore, this study refocuses on the debates around CSR and financial performance. In this case, corporate governance (CG) is inserted/included to strengthen the relationship. Insights obtained from this study may contribute to both theories and real practices of CSR policies. It could be done to improve the CSR understanding and management literature, as well as answer questions by different individuals or corporates regarding CSR, CG and financial performance.

\section{LITERATURE REVIEW AND HYPOTHESES}

\subsection{Corporate social responsibility and corporate profitability}

Many studies have been done to analyze the effect of CSR, including towards company's profitability. Corporates' profitability refers to the analysis of the ability of company to generate income. In this study, return on assets (ROA) is used to analyze the overall effectiveness of company's ability to generate profit with its assets (Gitman \& Zutter, 2012). Since customers may have different perspectives on the implementation of CSR policies, CSR becomes an important element to build and maintain corporate's reputation and profitability, as well as to increase competitive advantage of the company (Park, 2017; Devie et al., 2019). Hence, companies that intend to enhance their reputation should focus on providing products with better quality that is able to satisfy their customers (Park et al., 2014). Therefore, good social reputation will lead to increase of sales, especially to customers that are sensitive to social and environmental issues, thus increase corporate profits (Khojastehpour \& Johns, 2014). Profitable and large firms are also found to have higher CSR disclosure in their reports (Muttakin, Khan, \& Subramaniam, 2015). Moreover, there have been several studies done worldwide to analyze the impact of CSR on different company's outcome, including profitability. Yet, many have questioned as to whether the CSR implemented that incurred costs has created more benefits to it. However, this relationship between CSR and profitability still creates confusion and different results, especially inconsistency between developed and developing countries. Although empirical results reported in previous studies about the CSR and profitability relationship are mixed, these study findings mostly suggest a positive relationship between CSR and corporate profitability (LaGore, Mahoney, \& Thorne, 2013; Yu \& Choi, 2014; Cheung, 2010). Thus, this research study comes up with the following hypothesis.

\section{H1: CSR policies have a positive impact on corpo- rate profitability.}

\subsection{Good Corporate Governance and corporate's profitability}

The practice of companies' corporate governance creates a system for managing, monitoring and overseeing the whole resources of the company cost-effectively and functionally (Jackling \& Johl, 2009). Corporate governance is established to preserve the different interests of company's stakeholders that could give advantages for the company. A company with highly elevated Corporate Governance Perception Index (CGPI) indicates that it is managed with lucidity, responsibility, accountability, equity and independency. Consequently, the impact can be seen on the results of good corporate performance, such as ROE, ROA and EPS (Gompers et al., 2003). Some 
previous studies using similar governance index discovered that companies with more powerful stakeholder rights are likely to produce higher profits. Sheikh et al. (2013) also discovered a positive association between board size and company performance.

H2: GCG has a positive impact on corporate profitability.

\subsection{Corporate social responsibility and Good Corporate Governance}

Corporate social responsibility (CSR) is recently a critical component of companies and their stakeholders and persists to gain attention on the top of the corporate strategy. Previous study discloses that stronger commitments to CSR significantly and positively explain the prerequisites and provisions of directors, boards that put forth strong stewardship and strategic leadership roles. Additionally, the management of capital market hassles and that these different features combined compose the distinguishing characteristics of Good Corporate Governance (Lock \& Seele, 2015). Hence, CSR actively searches for a larger equilibrium or consistency between profit and ethics, which is consistent with corporate governance mechanism. Besides, corporate social responsibility is considered related to corporate governance, as governance is positively related to environmental strengths of a firm (Stuebs \& Sun, 2010). Moreover, previous study shows that Good Corporate Governance could not increase reputation of the company without social responsibility practices (Chalise, 2014). Recent studies have also analyzed the relationship between CSR and corporate governance from environmental performance perspective. In this case, the documentation of CSR performance of a firm has given benefits to support the corporate governance improvement effort of a company.

\section{H3: CSR policies have a positive impact on Good Corporate Governance.}

\subsection{Corporate profitability and value creation}

In the recent years, the influence of profitability or performance on firm value has gained much attention in many studies. In the competitive environment, companies are trying their best to sustain in the industry by optimizing their cost in order to gain more profit for their operations. Besides, management starts to concern about its investment plans to maximize shareholder's wealth and firm value (Chen, 2011). Understanding the relationship between profitability and value creation is also important to financial decision making of the firm. Some researches have also proven the positive correlation between profitability and firm value (AlNajjar \& Belkaoui, 1999; Crisóstomo et al., 2011; Osazuwa \& Che-Ahmad, 2016). It was proven that as the firm profit got greater, more earnings would be distributable to shareholders. This is also in line with the agency theory about the management ability in managing assets in order to maximize profit, creating shareholder's trust to company's quality of management. Thus, the higher the financial performance, the higher the value of the company.

\section{H4: CP has a positive impact on value creation.}

\subsection{Corporate social responsibility and value creation}

Departing from the conventional system of the prior studies (LaGore, Mahoney, \& Thorne, 2013; Yu \& Choi, 2014; Cheung, 2010; Gitman \& Zutter, 2012; Khojastehpour \& Johns, 2014) and instead of only focusing on a single financial measurement, a new method to measure firm's performance through value creation, known as economic value added (EVA), is used in this study. EVA is relevant for measuring the firm's performance, as it tells us how much the companies have created wealth for the stakeholders and how efficient the management has utilized the capital from the stakeholders. It is also known as economic profit, which is believed to be a special way of measuring profit. This is because EVA is measured taking account into all the opportunity or cost of the capital invested in the business (Steward, 2014). Relating to CSR, CSR strategies need to be developed in order to have a proper CSR policy that is essential to satisfy the firm's goals. It is crucial to pay more attention to actives that may add scores to company's value. If the company is showing a positive $\mathrm{VC}$, this also 
means that the company is working align with the corporate social responsibility. Besides, CSR creates value to the firm, as the firm could be able to differentiate them from the competitors and also to reduce its costs. As the firm is having adequate management, this creates also value for the business and society. This shows the positive correlation between the company investment in CSR and the value creation of the firm (Green \& Peloza, 2011). Likewise, there was also found a positive relationship between CSR and share price among companies in the UK, especially those with an environmentally sensitive industry such as electricity, mining, and gas. Accordingly, the fifth hypothesis made for this research study is:

H5: CSR policies have a positive impact on value creation.

\subsection{Good Corporate Governance and value creation}

Corporate governance includes making sure that shareholders' wealth, as well as the other stakeholders, are being taken into account in the management operation. This is also to prevent the corporate fraud and illegal accounting measure. Thus, value creation should be considered as to have Good Corporate Governance.Previous studies have found that significant corporate governance affects greater shareholder's rights in terms of profit, sales growth and ultimately the firm value. (Gompers, Ishii, \& Metrick, 2003). Some other researches are also showing different result for companies that implement Good Corporate Governance in developed, developing and underdeveloped countries. Positive relations are found between Good Corporate Governance practices and company's value (Klapper \& Love, 2002; Black, Jang, \& Kim, 2006).

H6: $\quad$ GCG has a positive impact on value creation.

\subsection{Corporate social responsibility, Good Corporate Governance and corporate profitability}

The stakeholder theory defines that companies should do CSR practices as to fulfil their responsibility to stakeholders and be able to maximize financial strength of the company. Supporting this, the corporate governance is describing as the intervening variable, strengthening the relationship of CSR and corporate profitability (CP). Besides, companies should have Good Corporate Governance in addition to implementation of CSR practices, in order to give positive impact to the performance. This is because the importance of corporate governance takes concern over the welfare of all stakeholders, not only shareholder. Previous researchers also found positive relationship between CSR and performance (Salama, Anderson, \& Toms, 2018; El Ghoul et al., 2011; Lourenco et al., 2011). In addition to this, some also did research on the potential impact on CSR practices on firm's sustainability and resulted in corporate governance positively affecting CSR disclosure (Li et al., 2010).

H7: $\quad$ GCG could mediate the relationship between CSR policies and corporate profitability.

\subsection{Corporate social responsibility, Good Corporate Governance and value creation}

CSR could be considered as activities that create values for improving the firm's reputation, which further lead to improvement of economic performance of the company. CSR not only creates financial benefit to the company, but also strategic advantage. By engaging in social responsibility practices, firms can gain trust and goodwill from stakeholders, which is also a competitive advantage (Kolk \& Pinkse, 2010). Research suggested that CSR activities would enhance firm's image and reputation (Vanhamme et al., 2012). CSR policies help in increasing the company's value and satisfy its goals. Companies doing CSR practices create positive value creation (VC) for the company. EVA, which is a measurement of value created or lost, is used to measure the performance and value creation made within the company. There is no previous research done regarding the relationship of CSR policies and value creation through GCG as intervening variable.

H8: $\quad$ GCG could mediate the relationship between CSR policies and value creation. 


\section{RESEARCH METHODOLOGY}

\subsection{Sample}

For the analysis of this study, Structural Equation Model (SEM) is used. This analysis model covers gathering of secondary data, testing of hypotheses and evaluation of variable correlations. The sample of the study involves firms that are consistently listed as having Good Corporate Governance by SWA-Magazine and Indonesia Institute for Corporate Governance (IICG) in 2016 and 2017. This study makes use of secondary data, including annual report, Bloomberg terminal and company's website.

Table 1. Summary of the sample observed

\begin{tabular}{|c|c|}
\hline Sampling criteria & $\begin{array}{l}\text { No. of } \\
\text { companies }\end{array}$ \\
\hline $\begin{array}{l}\text { Companies listed in CGPI in the years } 2016 \text { and } \\
2017 \text { by SWA-Magazine and IICG }\end{array}$ & 39 \\
\hline $\begin{array}{l}\text { Companies that were not consistently listed as } \\
\text { having GCG in the years } 2016 \text { and } 2017\end{array}$ & 13 \\
\hline $\begin{array}{l}\text { Companies that do not publish complete annual } \\
\text { report in the required period }\end{array}$ & 10 \\
\hline Number of companies which fulfill the criteria & 16 \\
\hline Total sample used in the research $(16 \times 2)$ & 32 firm-year \\
\hline
\end{tabular}

From the population of 39 companies included in the Corporate Governance Perception Index (CGPI) in 2016 and 2017, there are 23 companies that were not included in this research, as the companies did not fulfilled the requirement of the research. It was those companies not consistently listed in CGPI and not publishing a complete annual report in the required period. Hence, there are 16 companies, which fulfil the criteria and this was the number of the companies observed. All samples that are used in the research are 32 reports derived from 16 companies multiplied by 2 years of observation.

\subsection{Measures}

\section{Corporate social responsibility (CSR)}

CSR policies are measured using Kinder, Lydenberg, and Domini's (KLD) method, chosen as a basis of CSR level. This measurement has been widely used in previous leading management journals (P. Nguyen \& A. Nguyen, 2015; Li et al.,
2010; Jo \& Na, 2012; Devie et al., 2019). KLD provides benchmarking in 5 areas of CSR issue relevant to Indonesian companies, including diversity, community, environment, employee relation and products. In each of the KLD measurement, there are strengths and concerns. The strengths are considered to be positive CSR policies implemented, while concerns are as negative CSR policies implemented. If a company has a strength or even a concern, this would be given a " 1 " or " -1 " On the other hand, companies without any would be indicated with a " 0 ". After scoring 5 qualitative areas, the total score of strength and concerns should be calculated in order to get net CSR.

\section{Value creation}

EVA spread is used as the mesurement of value creation. EVA is a performance measurement to calculate the residual income from subtraction of additional charge from net operating profit after tax (Steward, 2014), which take into account cost of capital and cost of equity. EVA aims to figure out the economic profit of a company.

\section{Corporate profitability}

Return on asset (ROA) is used as the measurement of profitability. This is calculated by dividing net income by average total assets. ROA is also known as the overall effectiveness of company's management in generating profits with its assets (Gitman \& Zutter, 2012). ROA is widely used measurement of profitability in environmental studies (P. Nguyen \& A. Nguyen, 2015; Park, 2017; Devie et al., 2019).

\section{Good Corporate Governance}

This research has been using GCG as the intervening variables. The GCG was measured using the measurement of Corporate Governance Perception Index (CGPI) that was published by IICG and SWA-Magazine. This then had a scale of $0-100$ values. CGPI score with the predicate "very trusted" for companies with scores of 85-100, "trusted" for companies with scores 70-84, and "quite reliable" for companies with a score of 5569. The higher the score a company can get, the better the application of corporate governance is considered to be. 
Table 2. Variable definitions and data source

\begin{tabular}{|c|c|c|}
\hline Variable(s) & Definitions & $\begin{array}{l}\text { Data } \\
\text { source }\end{array}$ \\
\hline CSR policies & $\begin{array}{l}\text { Difference between total } \\
\text { strengths score and total } \\
\text { concerns score }\end{array}$ & $\begin{array}{l}\text { Annual and } \\
\text { company' } \\
\text { websites }\end{array}$ \\
\hline $\begin{array}{l}\text { Corporate } \\
\text { profitability } \\
\text { (ROA) }\end{array}$ & $\begin{array}{l}\text { Percentage of net income over } \\
\text { total assets }\end{array}$ & $\begin{array}{l}\text { Annual } \\
\text { report and } \\
\text { Bloomberg } \\
\text { terminal }\end{array}$ \\
\hline $\begin{array}{l}\text { Value creation } \\
\text { (EVA) }\end{array}$ & $\begin{array}{l}\text { Total of net operating profit } \\
\text { after tax divided by the } \\
\text { invested capital deducted by } \\
\text { the weighted average of cost } \\
\text { of capital }\end{array}$ & Bloomberg \\
\hline $\begin{array}{l}\text { Good Corporate } \\
\text { Governance }\end{array}$ & $\begin{array}{l}\text { Score of Good Corporate } \\
\text { Governance by SWA-Magazine } \\
\text { and IICG }\end{array}$ & $\begin{array}{l}\text { SWA- } \\
\text { Magazine }\end{array}$ \\
\hline
\end{tabular}

\subsection{Model}

This study helps to analyze the relationship of CSR to firm's performance in a positive, negative or neutral way, as well as the role of corporate governance (CG) as intervening variable that alters financial performance. A multivariate statistical model is used through validity, reliability, and collinearity tests (Kock, 2015). Validity test consists of convergent validity and discriminant validity test for each of the indicator.

Table 3. Combined loadings and cross-loadings

\begin{tabular}{l|c:c:c:c:c}
\hline \multicolumn{1}{c}{ Indicator } & CSR & GCG & CP & VC & $P$-value \\
\hline CSR & 1.00 & 0.00 & 0.00 & 0.00 & $<0.001$ \\
\hdashline CG & 0.00 & 1.00 & 0.00 & 0.00 & $<0.001$ \\
\hdashline ROA & 0.00 & 0.00 & 1.00 & 0.00 & $<0.001$ \\
\hdashline EVA & 0.00 & 0.00 & 0.00 & 1.00 & $<0.001$ \\
\hline
\end{tabular}

Table 3 shows that all the factor loading values of each indicators are above 0.5 . These value means that all indicators of CSR, CG, ROA and EVA, which were used to measure all the variables, have fulfilled the convergent validity test.

Table 4 shows discriminant validity. The discriminant validity is to compare the square root of average variance extracted (AVE) of each latent variable with the correlation between latent variables. If the square root of AVE of one indicator is larger than the other coefficient correlations in one parallel row of column, then the validity is fulfilled. The result of the discriminant validity is explained in Table 4.
Table 4. AVE table

\begin{tabular}{|c|c|c|c|c|}
\hline Indicator & CSR & GCG & CP & VC \\
\hline CSR & 1.00 & 0.010 & 0.717 & -0.061 \\
\hline CG & 0.010 & 1.00 & 0.157 & -0.149 \\
\hline ROA & 0.717 & 0.157 & 1.00 & -0.642 \\
\hline EVA & -0.061 & -0.149 & -0.642 & 1.00 \\
\hline
\end{tabular}

From Table 4 the square root AVE shows a figure of 1.00 for all results. These are also bigger than the coefficient correlation of the other variables.

\section{Composite reliability, Cronbach's alpha and collinearity}

From the composite reliability test, all the variables have the value of 1.00 , therefore composite reliability criteria are fulfilled. Not only that, result also has the Cronbach's alpha value of more than 0.6 , which is 1.00 for all the variables. Thus, all the variables have been fulfilled the criteria of reliability.

Table 5. Collinearity table

\begin{tabular}{l|c:c:c|c}
\hline $\begin{array}{c}\text { Variables } \\
\text { Criteria }\end{array}$ & CSR & GCG & CP & CV \\
\hline$R^{2}$ & - & 0.099 & 0.817 & 0.864 \\
\hline Adj. $R^{2}$ & - & 0.069 & 0.805 & 0.850 \\
\hline Full collinearity VIFs & 3.24 & 1.054 & 3.149 & 3.188 \\
\hline
\end{tabular}

In order to fulfill the collinearity test, VIFs must be less than 3.3 or 10 in a more relaxed criterion (Kock, 2015). According to Table 5, all variables have passed the multicollinearity tests.

\section{RESEARCH RESULTS AND ANALYSIS}

\subsection{Descriptive analysis}

Descriptive analysis is done through looking at the statistics of coefficients, which combined up as the data set, either in form of population as a whole or a sample as a part of the population. This explains the overview of the research data as a whole, which includes the total number of data used, minimum and maximum value, mean and standard deviation. 
Table 6. Descriptive statistics

\begin{tabular}{l|c:c:c|c}
\hline Indicators & Minimum & Maximum & Mean & STDEV \\
\hline CSR & 6.00 & 13.00 & 8.78 & 1.81 \\
CG & 72.68 & 93.32 & 84.92 & 5.32 \\
ROA & -45.60 & 22.07 & 1.30 & 10.51 \\
\hdashline EVA & -7.17 & 94.57 & 5.31 & 17.67 \\
\hline
\end{tabular}

Comparing the range to the CSR policies mean result in this research, the companies that are listed in Corporate Governance Perception Index (CGPI) and used in this research are presumably quite well. Besides, the profile GCG for its weighted average of 2016 and 2017 shows that GCG has one indicator with minimum and maximum value of 72.68 and 93.32. The samples in this research are those companies consistently listed as having a good corporate governance. It means that the companies show good performance and are considered as trusted companies, which lies within the range of 70-84. Besides, the mean value of the GCG score is 84.92 , which, categorized as "most trusted companies", lies within 85-100. Thus, it indicates that companies begin to be concerned about their corporate governance.

\subsection{Hypotheses test (direct, intervening and total effects)}

The hypothesis test was done by using the $T$-test and re-sampling. In this research, the hypothesis test was divided into 3 parts: direct effect, mediation variable and the total effect of the variables.

\subsubsection{Direct effect}

Table 7. Path coefficient and $p$-values

\begin{tabular}{|c|c|c|c|c|}
\hline $\begin{array}{l}\text { Independent// } \\
\text { control variable }\end{array}$ & $\begin{array}{l}\text { Dependent } \\
\text { variable }\end{array}$ & $\begin{array}{c}\text { Path } \\
\text { coefficient }\end{array}$ & $P$-value & Note \\
\hline CSR & $\mathrm{CP}$ & 0.73 & $<0.01$ & $\begin{array}{l}\text { Highly } \\
\text { significant }\end{array}$ \\
\hline CSR & $\begin{array}{l}\text { Value } \\
\text { creation }\end{array}$ & -0.02 & 0.45 & Insignificant \\
\hline CSR & GCG & 0.32 & 0.02 & Significant \\
\hline GCG & $\mathrm{CP}$ & 0.25 & 0.06 & $\begin{array}{l}\text { Weakly } \\
\text { significant }\end{array}$ \\
\hline GCG & $\begin{array}{l}\text { Value } \\
\text { creation }\end{array}$ & 0.07 & 0.35 & Insignificant \\
\hline Profitability & $\begin{array}{l}\text { Value } \\
\text { creation }\end{array}$ & -0.93 & $<0.01$ & $\begin{array}{l}\text { Highly } \\
\text { significant }\end{array}$ \\
\hline
\end{tabular}

Figure 1 and Table 7 show that corporate social responsibility policies affect corporate governance with the coefficient value of 0.32 and $p$-value 0.02 , and it also gives effect on corporate profitability with coefficient value of 0.73 and $p<0.01$. In other words, the higher score of CSR policies will increase the profitability of the company (ROA), supported by the $p$-value of lower than $5 \%$ significance level of both. This also means that Hypothesis 1 is accepted, since the relationship between CSR policies and profitability is positive, highly significant and direct, hence, Hypothesis 3 is also accepted, as the CSR has a direct positive relationship with Good Corporate Governance. The Hypothesis 1 result is in line with the stakeholder theory that when firms put CSR practices into consideration, they will read a better performance (Yu \& Choi,

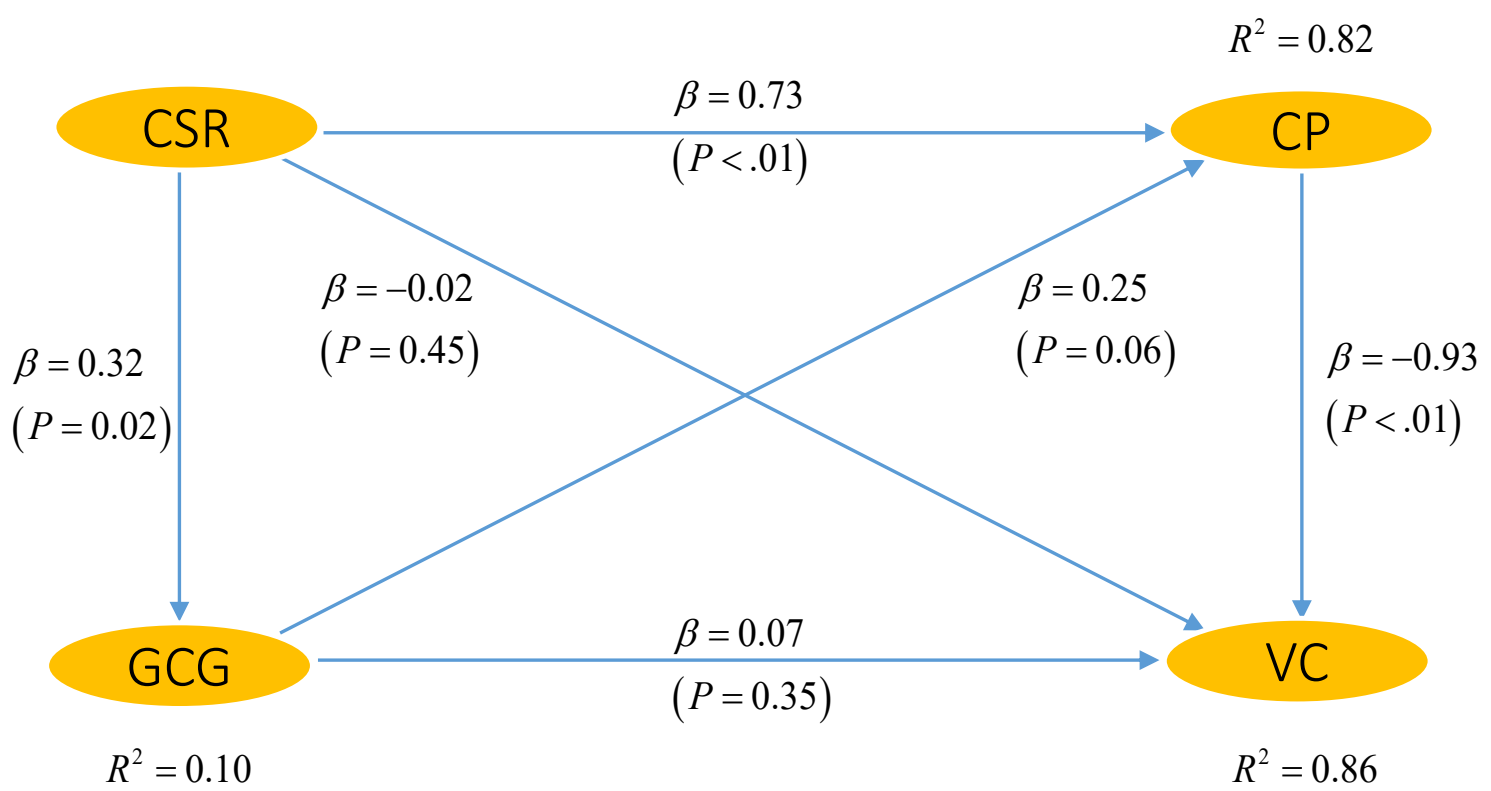

Figure 1. Structural model result 
2014). On the other hand, the acceptance of the Hypothesis 3 is in line with the belief that higher commitments of CSR could strongly impact on the qualifications of directors and other members of the company, which combined into a Good Corporate Governance hallmark. Besides, Good Corporate Governance may not be able to increase reputation of the company without also taking care of the social responsibility practices in the company (Chalise, 2014). Moreover, Good Corporate Governance is showing a positive correlation of 0.25 and $p=0.06$, which is deemed to be weakly significant. Thus, Hypothesis 2 explains the relationship between GCG and profitability that is positive but weakly significant, and acceptable. This means that when companies are directed and controlled properly, the company could be more efficient in the work and operation, which then results in better performance. In this case, an increase on efficiency of the work will impact the profit of the company (Sheikh et al., 2013).

Furthermore, the relationship of CSR policies to value creation shows a value of -0.02 with $p=0.45$, which means that a higher score of CSR policies, the value of the firm will decrease and this is insignificant. Therefore, Hypothesis 5 is rejected. This is supported by the theory that CSR practices could create long-term value for the company's financial performance instead of giving short-term impact (Gregory, Tharyan, \& Christidis, 2013). Moreover, the data also describe an insignificant effect of Good Corporate Governance on value creation of 0.07 and $p=0.35$. This means that there is an insignificant positive relationship between the two variables, so Hypothesis 6 is rejected. It possibly happens because corporate governance implementation in a company cannot directly influence the firm's value, but it takes some time. Likewise, the relationship between profitability and value creation shows a negative value of 0.93 with $p<0.01$. This means that profitability doesn't give a rise to value creation as it increases. Thus, Hypothesis 4 is also rejected. If profit does not provide an increase on funding of the company, the firm still has to decrease its dividends or choose to increase its debt level for the funding. Both of them give negative impact on the markets and usually result in a decrease of share price and destroy the shareholder's value.

\subsubsection{Intervening effect}

Table 8 shows the indirect effect and $p$-values of intervening variables.

Table 8. Indirect effect and $p$-values

\begin{tabular}{|c|c|c|c|c|}
\hline $\begin{array}{l}\text { Independent } \\
\text { variable }\end{array}$ & $\begin{array}{c}\text { Intervening } \\
\text { variable }\end{array}$ & $\begin{array}{l}\text { Dependent } \\
\text { variable }\end{array}$ & $\begin{array}{c}\text { Path } \\
\text { coefficient }\end{array}$ & P-value \\
\hline CSR & $\begin{array}{c}\mathrm{CP} \\
\mathrm{GCG}\end{array}$ & VC & -0.657 & $<0.001$ \\
\hline CSR & GCG & $\mathrm{CP}$ & 0.079 & 0.258 \\
\hline GCG & $\mathrm{CP}$ & VC & -0.233 & 0.023 \\
\hline
\end{tabular}

Looking at Table 8 the $p$-value of CSR towards corporate's profitability with Good Corporate Governance as the mediating variable is 0.258 . This figure shows a big percentage, which is more than $5 \%$ significant, thus this is considered to be insignificant. It can be concluded that Good Corporate Governance fails to act as a mediating variable, therefore, Hypothesis 7 is rejected. Additionaly, Hypothesis 8 is also rejected, since the mediating variables show a significant value of $0.023(<0.05)$ with path coefficient for this being at -0.233 . Hence, corporate profitability mediates the Good Corporate Governance and value creation, but negatively.

\subsubsection{Total effect}

The total effect refers to the $p$-values for all variables included in the research. This includes all the direct and indirect effect and being discussed further in Table 9.

Table 9. Total effect and $p$-values

\begin{tabular}{l|c|c|c|c}
\hline Variables & CSR & GCG & CP & VC \\
\hline CSR & - & - & - & - \\
GCG & 0.32 & & & \\
& $(=0.023)$ & - & - & - \\
CP & 0.807 & 0.25 & & \\
& $(<0.001)$ & $(=0.06)$ & - & - \\
VC & -0.752 & -0.167 & -0.93 & \\
& $(<0.001)$ & $(=0.158)$ & $(<0.001)$ & - \\
\hline
\end{tabular}

The detailed calculation of the absolute contribution between variables is discussed below:

$$
\begin{gathered}
\text { CSR to } \mathrm{GCG}=(0.32)^{2} \times 100 \%=10.24 \% \\
\text { CSR to } \mathrm{CP}=(0.807)^{2} \times 100 \%=65.12 \% \\
\text { CSR to } \mathrm{VC}=(-0.752)^{2} \times 100 \%=56.55 \%
\end{gathered}
$$




$$
\begin{gathered}
\text { GCG to } \mathrm{CP}=(0.25)^{2} \times 100 \%=6.25 \% \\
\text { GCG to } \mathrm{VC}=(-0.167)^{2} \times 100 \%=2.79 \% \\
\mathrm{CP} \text { to } \mathrm{VC}=(-0.93)^{2} \times 100 \%=86.49 \%
\end{gathered}
$$

The calculation of the overall total effect is taking account both direct and indirect variables. As concluded in the results, the strongest absolute effect is the relationship between corporate profitability and value creation, which is $86.49 \%$ as compared to other variables. Meanwhile, the relationship between corporate governance and value creation holds the weakest effect as compared to other variables of only $2.79 \%$. The correlation between CSR and profitability is $65.12 \%$, which is higher than if corporate governance acts as the mediating variable. This result is found when adding the result of CSR to corporate governance of $10.24 \%$ and corporate governance to profitability $6.25 \%$, which comes out with value of $16.49 \%$. Thus, it can be concluded that the indirect effect does not exist between those two variables and corporate governance does not mediate the relationship between CSR and profitability. In addition, looking at the corporate governance as the mediating variable for CSR and VC relationship, there is also no indirect effect. This is concluded from the value of CSR to value creation of $56.55 \%$. The value is higher than the sum of CSR to corporate governance of $10.24 \%$ and corporate governance to value creation of $2.79 \%$, summed up to $13.03 \%$. Thus, indirect effect does not exist when corporate governance mediates the second relationship. In conclusion, corporate governance does not have indirect effect for both of the relationship, when it mediates the relationship between CSR and profitability and CSR and value creation.

\section{CONCLUSION, CONTRIBUTION AND IMPLICATION}

The objective of this research paper is to analyze the impact of corporate social responsibility (CSR) policies towards profitability and value creation, as well as whether the corporate governance (CG) is able to become the mediation variable to the relationship. The analysis shows a significantly positive relationship between CSR and profitability. Our contribution to this study is that higher CSR practices and corporate governance are associated with higher profitability obtained by the company, as proposed in $\mathrm{H} 1$ and $\mathrm{H} 2$. This result indicates that not only consumers are concerned about the products they consume, but also the manufacturers. Thus, companies with higher CSR practices could lead to increase in sales and profit. Besides, Good Corporate Governance makes the company work more efficiently and effectively, which reduces cost or increasing margin and increases profitability. Companies with Good Corporate Governance ensure a socially responsible way of how the companies are run and a lucidly ethical basis for complying with the accepted norms of the society where they operate. Hence, CSR actively searches for a larger equilibrium or consistency between profit and ethics, which is consistent with corporate governance mechanism as proved in $\mathrm{H} 3$.

However, profitability has negative effect on the value creation measured. Unless profits provide the increased funding, the firm has to lower the dividends or raise the debt level. The market perceives them negatively and generally leads to price drop, finally damaging shareholder value. It means that for some Indonesian companies listed in Corporate Governance Perception Index (CGPI), the CSR practices level still cannot create long-term performance in terms of EVA.

\section{REFERENCES}

1. AlNajiar, F. K., \& Belkaoui, A. R. (1999). Multinationality, profitability and firm value. Managerial Finance, 25(12), 31-41. https://doi. org/10.1108/03074359910766325

2. Black, B., Jang, H., \& Kim, W. (2006). Does Corporate
Governance Predict Firms' Market Values? Evidence from Korea. Journal of Law, Economics, \& Organization, 22(2), 366-413. https://doi.org/10.1093/jleo/ ewj018

3. Crisóstomo, V. L., Freire, F. D., \& Vasconcellos, F. C.
(2011). Corporate Social Responsibility, Firm Value, and Financial Performance in Brazil. Social responsibility journal, 7(2), 295-309. https://doi. org/10.1108/17471111111141549

4. Chalise, M. (2014). Impact of Corporate Social Responsibility 
on Corporate Governance and Reputation in Nepalese Commercial Banks. Nepal Journals, 22(1-2), 27-36. https:// doi.org/10.3126/jodas.v22i1 2.13462

5. Chen, S. (2011). Capital structure determinants: An empirical study in Taiwan. African Journal of Business Management, 5(2), 10974-10983. http://dx.doi. org/10.5897/AJBM10.1334

6. Cheung, Y. (2010). Does corporate social responsibility matter in Asian emerging markets? Journal of Business Ethics, 92(3), 401413. Retrieved from https://link. springer.com/article/10.1007/ s10551-009-0164-3

7. Detthamrong, U., Chancharat, N., \& Vithessonthi, C. (2017). Corporate governance, capital structure and firm performance: Evidence from Thailand. Research in International Business and Finance, 42(31), 689-709. https://doi.org/10.1016/j. ribaf.2017.07.011

8. Devie, D., Kamandhanu, J., Tarigan, J., \& Hatane, S. E. (2019). Do environmental performance and disclosure bring financial outcome? Evidence from Indonesia. World Review of Science, Technology and Sustainable Development, 15(1), 66-86 https://doi.org/10.1504/ WRSTSD.2019.098681

9. El Ghoul, S., Guedhami, O., Kwok, C., \& Mishra, D. (2011). Does Corporate Social Responsibility Affect the Cost of Capital? Journal of Banking \& FInance, 35(9), 23882406. https://doi.org/10.1016/j. jbankfin.2011.02.007

10. Gitman, L., \& Zutter, C. (2012). Principles of Managerial Finance. Harlow: Pearson Education Limited.

11. Gregory, A., Tharyan, R., \& Christidis, A. (2013). Constructing and testing alternative versions of the Fama-French and Carhart models in the UK. Journal of Business Finance \& Accounting, 40(1-2), 172-214. https://doi. org/10.1111/jbfa.12006

12. Green, T., \& Peloza, J. (2011). How does corporate social responsibility create value

for consumers? Journal

of Consumer Marketing,

28(1), 48-56. https://doi.

org/10.1108/07363761111101949

13. Gompers, P., Ishii, J., \& Metrick, A. (2003). Corporate Governance and Equity Prices. Quarterly Journal of Economics, 118(1), 107-155. Retrieved from https:// papers.ssrn.com/sol3/papers. cfm?abstract_id $=278920$

14. Jackling, B., \& Johl, S. (2009). Board structure and firm performance: Evidence from India's top companies. Corporate Governance: An International Review, 17(4), (492-509). http:// dx.doi.org/10.1111/j.14678683.2009.00760.x

15. Jo, H., \& Na, H. (2012). Does CSR Reduce Firm Risk? Evidence from Controversial Industry Sectors. Journal of Business Ethics, 110(4), 441-456. https://DOI.org/10.1007/ s10551-012-1492-2

16. Klapper, L. F., \& Love, I. (2002). Corporate Governance, Investor Protection and Performance in Emerging Markets (World Bank Policy Research Working Paper, No. 2818). http://dx.doi. org/10.2139/ssrn.303979

17. Khojastehpour, M., \& Johns, R. (2014). The effect of environmental CSR issues on corporate/brand reputation and corporate profitability. European Business Review, 26(4), 330-339. https://doi.org/10.1108/EBR-032014-0029

18. Kock, N. (2015). WarpPLS 5.0 User Manual (108 p.). Laredo, Texas: ScriptWarp Systems.

19. Kolk, A., \& Pinkse, J. (2010). The integration of corporate governance in corporate social responsibility disclosures. Corporate Social Responsibility and Environmental Management, 17(1), 15-26. https://doi. org/10.1002/csr.196

20. LaGore, W., Mahoney, L. S., \& Thorne, L. (2013). A research note on standalone corporate social responsibility reports: Signaling or greenwashing? Critical Perspectives on Accounting, 24(4-5), 350-
359. https://doi.org/10.1016/j. cpa.2012.09.008

21. Li, S., Fetscherin, M., Alon, I., Lattemann, C., \& Yeh, K. (2010). Corporate Social Responsibility in Emerging Markets. Management International Review, 50(5), 635-654. https://doi.org/10.1007/ s11575-010-0049-9

22. Lourenco, I., Branco, M., Curto, J., \& Eugénio, T. (2011). How Does the Market Value Corporate Sustainability Performance? Journal of Business Ethics, 108(4), 417-428. https://doi.org/10.1007/ s10551-011-1102-8

23. Lock, I., \& Seele, P. (2016). CSR governance and departmental organization: a typology of best practices. Corporate Governance: The International Journal of Business in Society, 16(1), 211-230. https://doi.org/10.1108/CG-012015-0010

24. Muttakin, M. B., Khan, A., \& Subramaniam, N. (2015). Firm Characteristics, Board Diversity and Corporate Social Responsibility: Evidence from Bangladesh. Pacific Accounting Review, 27(3), 353-372. https://doi. org/10.1108/PAR-01-2013-0007

25. Nguyen, P., \& Nguyen, A. (2015). The effect of corporate social responsibility on firm risk. Social Responsibility Journal, 11(2), 324339. https://doi.org/10.1108/SRJ08-2013-0093

26. Osazuwa, N. P., \& Che-Ahmad, A. (2016). The moderating effect of profitability and leverage on the relationship between ecoefficiency and firm value in publicly traded Malaysian firms. Social Responsibility Journal, 12(2), 295-306. https://doi.org/10.1108/ SRJ-03-2015-0034

27. Park, S. (2017). Corporate social responsibility, visibility, reputation and financial performance: empirical analysis on the moderating and mediating variables from Korea. Social Responsibility Journal, 13(4), 856871. https://doi.org/10.1108/SRJ01-2017-0012

28. Park, J., Lee, H., \& Kim, C. (2014). Corporate social responsibilities, 
consumer trust and corporate reputation: South Korean consumers' perspectives. Journa of Business Research, 67(3), 295302. https://doi.org/10.1016/j. jbusres.2013.05.016

29. Salama, A., Anderson, K., \& Toms, J. (2018). Does community and environmental responsibility affect firm risk? Evidence from UK panel data 1994-2006. Abacus, 17(4), 57-60. https://doi.org/10.1111/ j.1467-8608.2011.01617.x

30. Sheikh, A., Wang, Z., \& Khan, S. (2013). The impact of internal attributes of corporate governance on firm performance: Evidence from Pakistan. International Journal of Commerce and Management,
23(1), 38-55. https://doi. org/10.1108/10569211311301420

31. Steward, B. (2014). The Role of the Cost of Capital in EVA and in Corporate ValueBased Management. John Wiley \& Sons. https://doi. org/10.1002/9781118846780.ch33

32. Stuebs, M., \& Sun, L. (2010). Business Reputation and Labor Efficiency, Productivity and Cost. Journal of Business Ethics, 96(2), 265-283. https://doi.org/10.1007/ s10551-010-0464-7

33. Vargas, L. (2016). Corporate Social Responsibility and Financial Performance: GIC's Share Price Value Impact. Corporate Responsibility and Stakeholding,
10, 165-177. Retrieved from https://www.emeraldinsight. com/doi/full/10.1108/S2043 052320160000010012

34. Vanhamme, J., Lindgreen, A., Reast, J. D., \& Popering, N. (2012). To Do Well by Doing Good: Improving Corporate Image Through Cause-Related Marketing. Journal of Business Ethics, 109(3), 259-274. https://doi. org/10.1007/s10551-011-1134-0

35. Yu, Y., \& Choi, Y. (2014). Corporate social responsibility and firm performance through the mediating effect of organizational trust in Chinese firms. Chinese Management Studies, 8(4), 577592. https://doi.org/10.1108/CMS10-2013-0196 